\title{
APLIKASI SIMULASI MEMBUAT SIM C BERBASIS ANDROID
}

\author{
Achmad Syaiful Anam 1), Retno Wardhani ${ }^{2)}$, Masruroh ${ }^{3)}$ \\ ${ }^{1)}$ Mahasiswa Program Studi Teknik Informatika, Fakultas Teknik, Universitas Islam Lamongan \\ ${ }^{2,3)}$ Dosen Program Studi Teknik Informatika, Fakultas Teknik, Universitas Islam Lamongan \\ E-mail: syaiful6anam@gmail.com ${ }^{1}$,retzno@yahoo.com ${ }^{2}$,ismi_masruroh@gmail.com ${ }^{3}$
}

\begin{abstract}
ABSTRAK
SIM (Surat Izin Mengemudi) adalah bukti registrasi dan identifikasi yang diberikan oleh Polri kepada seseorang yang telah memenuhi persyaratan administrasi, sehat jasmani dan rohani, memahami peraturan lalu lintas dan terampil mengemudikan kendaraan bermotor. Hasil survey menunjukkan belum semua orang yang memiliki kendaraan roda dua memiliki SIM C, 8 dari 10 orang diantaranya beralasan takut dan belum mengerti tata cara untuk membuat SIM C. Seringnya pengguna kendaraan roda dua belum lulus saat ujian SIM C dikarenakan belum sepenuhnya mengetahui teori tentang rambu dan marka jalan maupun mahir dalam berkendara sepeda motor. Berdasarkan permasalahan tersebut dibuatlah Aplikasi Simulasi Membuat SIM C berbasis Android sebagai judul penelitian. Aplikasi ini dirancang menggunakan Construct 2, tahapan merancang aplikasi ini dimulai dengan pengumpulan data (soal buta warna, tes teori, informasi tes praktek, dan informasi tentang SIM), selanjutnya mendesain interface pada program dan kemudian merancang alur sistem program, terakhir melakukan uji coba Black Box dan uji coba user. Hasil implementasi uji coba internal (pembuatan) aplikasi ini berhasil berdasarkan uji coba menggunakan metode Black Box. Hasil implementasi uji coba user berdasarkan perhitungan kuisoner responden sebanyak 50 orang menggunakan metode skala likert diperoleh hasil 89\%. Maka dapat diambil kesimpulan bahwa aplikasi simulasi membuat SIM C ini dikategorikan sangat baik.
\end{abstract}

Kata kunci : Simulasi SIM C, Construct 2, Android.

\begin{abstract}
Driving license is a registration proof and identification that is given by Indonesian Nation Police to someone who is fulfilled the administrative requirement, physically and mentally healthy, understand the traffic regulation, and skilled motorcycle driving. The survey result shows that not all people who have motorcycle have $C$ driving license, eight of ten people say that they are afraid and have not understood the procedure of making $C$ driving license yet. The motorcycle driver have not passed the $C$ driving license test frequently because they have not understood the theory of traffic sign and road marking, and driving the motorcycle yet. Based on that problem $C$ Driving license Simulation Application Android Based is made as the research tittle. This application is developed based on Construct 2, the stages of developing Application is started from collecting the data (color-blind test, theory test, practice test's information, and driving license information), then designing the program's interface and program system's groove, and the last one is black box testing and user testing. The implementation result of internal test (developing) Application test is based on Black Box method. Implementation result of user test based on the questionnaire from 50 respondents used likert scale was gotten $89 \%$. So, it can be concluded that C Driving license Simulation Application is the good one.
\end{abstract}

Keywords : C Driving license Simulation, Construct 2, Android. 


\section{PENDAHULUAN}

SIM (Surat Izin Mengemudi) adalah bukti registrasi dan identifikasi yang diberikan oleh Polri kepada seseorang yang telah memenuhi persyaratan administrasi, sehat jasmani dan rohani, memahami peraturan lalu lintas dan terampil mengemudikan kendaraan bermotor. Setiap orang yang mengemudikan Kendaraan Bermotor di Jalan wajib memiliki Surat Izin Mengemudi sesuai dengan jenis Kendaraan Bermotor yang dikemudikan (Pasal 77 ayat (1) UU No.22 Tahun 2009). Setiap pengemudi kendaraan bermotor wajib memiliki SIM peraturan ini tercantum pada Pasal 18 (1) UU No. 14 Th 1992 tentang Lalu-lintas dan Angkutan Jalan, bahwa setiap pengemudi kendaraan bermotor diwilayah wajib memiliki Surat Ijin Mengemudi (SIM). Menurut data dari BPS (Badan Pusat Statistik) jumlah kendaraan roda dua tiap tahunnya mengalami peningkatan. Peningkatan kepemilikan kendaraan roda dua tidak diimbangi dengan meningkatnya kepemilikan SIM C sebagai syarat mengendarai kendaraan roda dua. Hasil survey menunjukkan belum semua orang yang memiliki kendaraan roda dua memiliki SIM C, 8 dari 10 orang diantaranya beralasan takut dan belum mengerti tata cara untuk membuat SIM C. Seringnya pengguna kendaraan roda dua belum lulus saat ujian SIM C dikarenakan belum sepenuhnya mengetahui teori tentang rambu dan marka jalan maupun mahir dalam berkendara sepeda motor.

Berdasarkan permasalahan diatas dibuatlah Aplikasi Simulasi Membuat SIM C berbasis Android sebagai judul penelitian. Aplikasi ini diharapkan dapat membantu masyarakat untuk mengetahui alur dalam pembuatan SIM C dan membantu masyarakat untuk berlatih dalam mempersiapkan uji tes buta warna, ujian teori, maupun ujian praktek.

\section{METODE PENELITIAN}

Metodologi penelitian merupakan sebuah cara yang dilakukan oleh peneliti untuk memperoleh sebuah atau sejumlah data yang akan digunakan dalam proses penelitian untuk memecahkan persoalan yang sedang diteliti. Pemilihan metodologi penelitian yang tepat sangat berpengaruh dalam proses penelitian yang akan dilakukan. Dalam penelitian ini peneliti menggunakan metode sebagai berikut:

1. Dokumentasi

Dokumentasi ini dilakukan untuk mengumpulkan data tentang informasi yang dibutuhkan dan berkaitan dalam pembuatan Aplikasi Membuat SIM C berbasis Android.

2. Kepustakaan

Kepustakaan ini dilakukan mendapatkan konsep-konsep teoritis dengan cara menganalisa data pada literatur (pustaka) dan media lain yang dapat membantu dalam pemecahan masalah.

3. Kuisoner

Kuisoner ini disusun dalam bentuk pertanyaan untuk mengumpulkan data tanggapan pengguna terhadap aplikasi yang telah dibuat.

4. Observasi

Metode ini digunakan untuk mendapatkan data hasil uji coba aplikasi menggunakan Black Box Testing yang mengevaluasi hanya dari tampilan luarnya (interface) dan hanya mengetahui input dan output dari aplikasi simulasi membuat SIM C berbasis android.

\section{ANALISA DAN PERANCANGAN SISTEM Kebutuhan Fungsional}

Kebutuhan fungsional adalah kebutuhan pengguna sehari-hari yang akan dimiliki oleh sistem, dimana kebutuhan ini akan digunakan oleh pengguna. Dalam kebutuhan fungsional ini akan dipaparkan mengenai fitur-fitur yang akan dimasukkan kedalam aplikasi yang akan dibuat. Fitur-fitur tersebut antara lain sebagai berikut :

1. Simulasi bersifat continue

2. Terdapat tes buta warna

3. Terdapat tes teori dan praktek

4. Terdapat video turotial

5. Kontrol sound atau suara simulasi

\section{Perancangan Sistem}

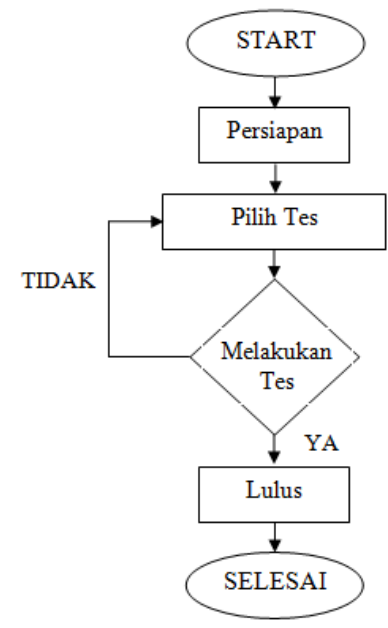

Gambar 1. Bagan Alur Sistem

Gambar 1 bagan alur sistem ini menjelaskan tentang proses aplikasi dimulai dari start 
dilanjut dengan menu persiapan (persiapan berkas yang dibutuhkan sebelum pembuatan SIM C), kemudian lanjut dengan memilih tes, tes pertama pengguna masuk ke menu tes buta warna, jika tidak lulus maka kembali ke menu tes buta warna dan jika lulus lanjut ke tes selanjutnya. Tes selanjutnya yakni tes teori SIM $\mathrm{C}$, jika di test teori SIM C pengguna tidak lulus maka kembali ke menu tes teori SIM C dan jika lulus maka lanjut ke tes selanjutnya. Tes selanjutnya yakni test praktek SIM C, jika di test praktek SIM C pengguna tidak lulus maka kembali ke menu tes praktek SIM C dan jika lulus tes praktek kembali ke menu utama.

\section{Perancangan Proses}

Dalam membangun aplikasi simulasi membuat SIM C berbasis android sistem analis memerlukan beberapa tahapan perancangan proses yaitu menggunakan UML (Unified Modelling Language) meliputi: Use Case, Sequence Diagram, Activity Diagram dan Class Diagram.

\section{Use Cse Diagram}

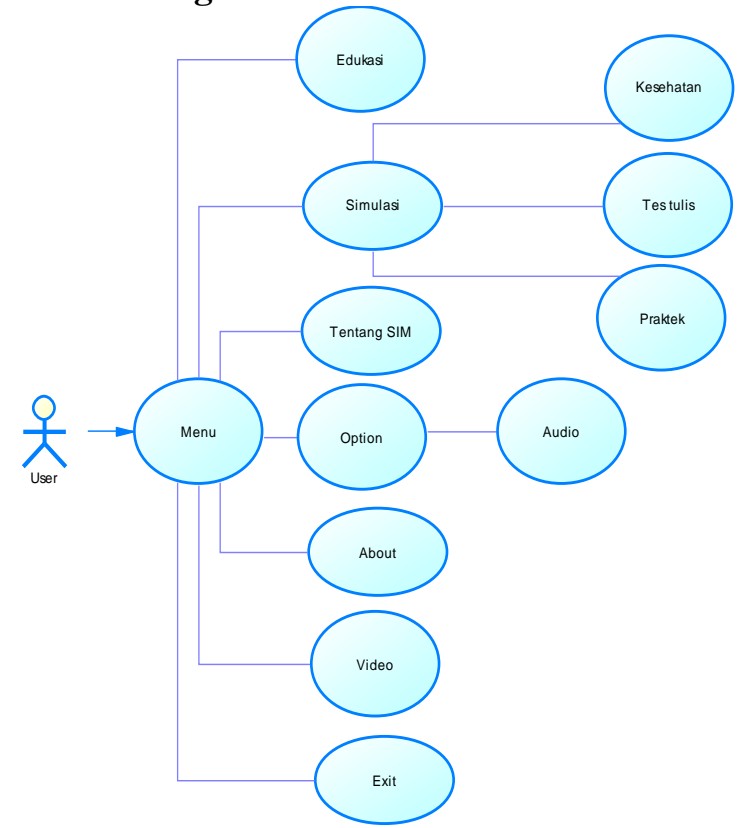

Gambar 2. Use Case Diagram Aplikasi Simulasi Membuat SIM C

Tampilan menu user pada gambar 2 memiliki menu start, reset, tentang sim, about dan exit. Jika user klik menu start maka akan terdapat beberapa menu pilihan yaitu menu edukasi persiapan berkas, menu simulasi tes kesehatan, menu simulasi tes tulis, dan menu simulasi praktek. Reset berfungsi jika user ingin kembali ke menu sebelumnya. Pada menu tentang sim hanya berisi informasi tentang sim. About merupakan menu informasi tentang aplikasi. Menu exit berfungsi untuk menutup aplikasi.

\section{Sequence Diagram}

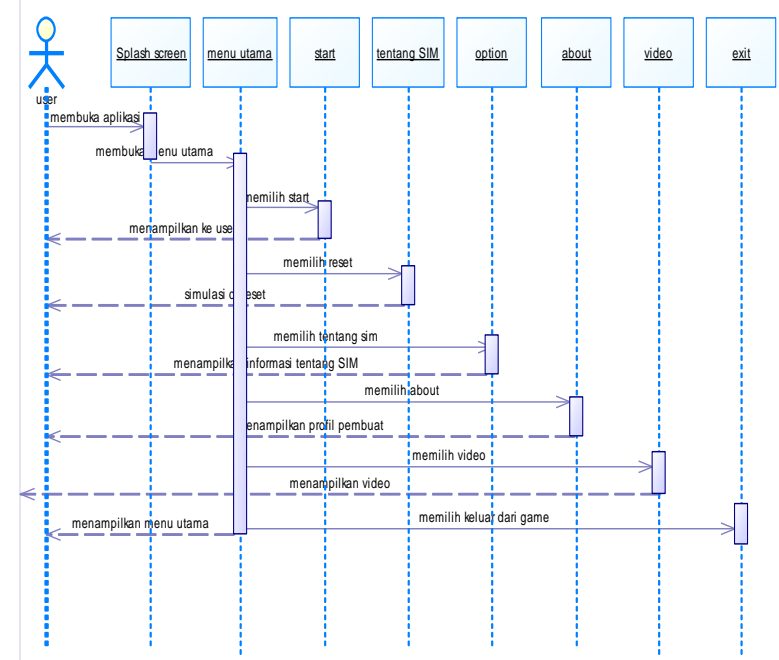

Gambar 3. Sequence Diagram Menu Utama

Pada gambar 3 sequence diagram menu utama ini memiliki beberapa menu yaitu spalsh screen, menu utama, start, tentang SIM, option, about, video, dan exit. Jika user membuka aplikasi lalu membuka menu utama dan memilih start maka akan tampil menu yang terdapat pada start dan user dapat melihat sesuai yang diinginkan. Jika memilih menu reset maka simulasi di reset. Jika user memilih tentang SIM maka akan tampil informasi tentang SIM. Jika memilih menu about maka tampil profil pembuat. Jika user memilih tombol exit maka memilih keluar dari aplikasi tersebut dan akan kembali ke menu utama.

\section{Activity Diagram}

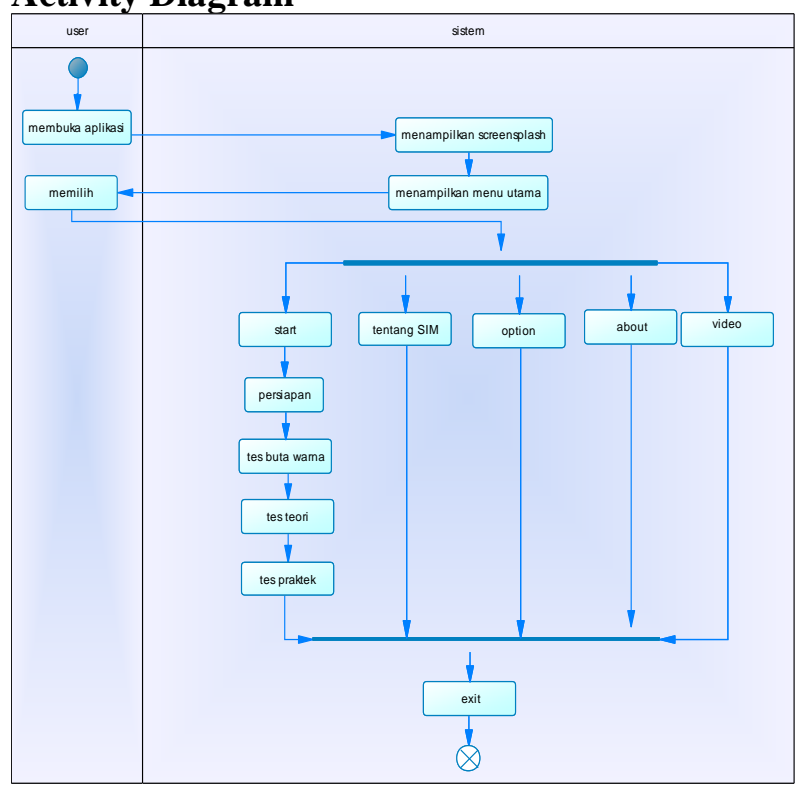

Gambar 4. Activity Diagram Aplikasi Simulasi Membuat SIM C 
Pada gambar 4 activity diagram aplikasi simulasi membuat SIM C ini user membuka aplikasi dan sistem menampilkan splash screen lalu tampil menu utama, user memilih menu yang terdapat pada aplikasi simulasi membuat SIM C yaitu start, reset, tentang SIM, dan about. Pada menu start terdapat beberapa tahapanya itu persiapan, tes buta warna, tes teori, dan tes praktek. Jika selesai maka pilih exit untuk keluar dari aplikasi tersebut.

\section{IMPLEMENTASI}

\section{Desain Program}

Desain program ini berisi tentang tampilan dan cara penggunaan masing-masing form dari sistem aplikasi simulasi membuat SIM C berbasis android ini. Dengan begitu pengguna dapat menjalankan aplikasi ini dengan mudah dan tanpa ada kesulitan. Untuk itu lebih jelasnya pembuat aplikasi ini menjelaskan satu persatu dalam menggunakan aplikasi simulasi membuat SIM C ini.

\section{Form Loading}

Form loading adalah dimana sebuah form pembukaan dalam sebuah aplikasi simulasi membuat SIM C, saat pertama kali menjalankan aplikasi kurang dari 20 detik, screen akan langsung berpindah ke screen menu utama. Berikut 5 dari form loading pada aplikasi simulasi membuat SIM C berbasis android.

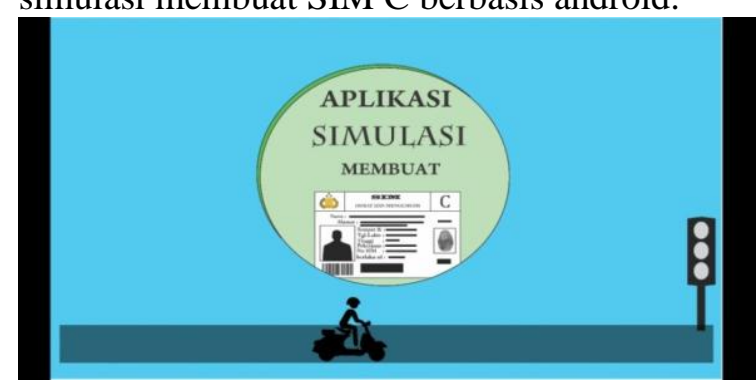

\section{Form Menu Utama}

\section{Gambar 5 Form Loading}

Form menu utama adalah form dimana yang didalamnya terdapat menu utama dari fitur-fitur aplikasi. Dimana didalam menu utama terdapat 6 tombol yaitu :

a. Form Start adalah tombol yang didalamnya terdapat tombol pilihan lagi yaitu tombol edukasi persiapan, buta warna, tes teori, dan tes praktek.

b. Form tentang SIM adalah tombol yang berisi tentang informasi SIM.

c. Form option adalah tombol yang digunakan untuk mengontrol audio di aplikasi simulasi membuat SIM C.

d. Form about adalah tombol yang berisi tentang profil pembuat. e. Form video adalah tombol yang berisi tentang tutorial tes praktek yang baik dan benar.

f. Form exit adalah tombol yang nantinya pengguna aplikasi simulasi membuat SIM C ini akan memilih keluar atau tidak dari aplikasi tersebut.

Berikut gambar 6 dari form menu utama pada aplikasi simulasi membuat SIM C berbasis android.

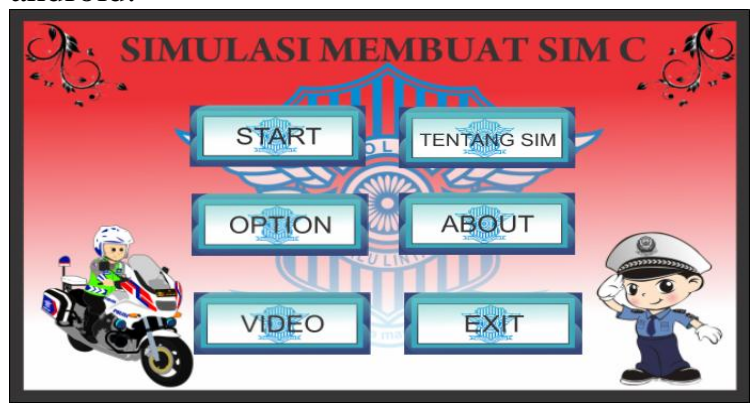

Gambar 6 Form Menu Utama

\section{Form Menu Start}

Form start adalah form yang dimana didalamnya terdapat menu start dari fitur-fitur aplikasi. Berikut gambar 7 dari form start pada aplikasi simulasi membuat SIM C berbasis android.

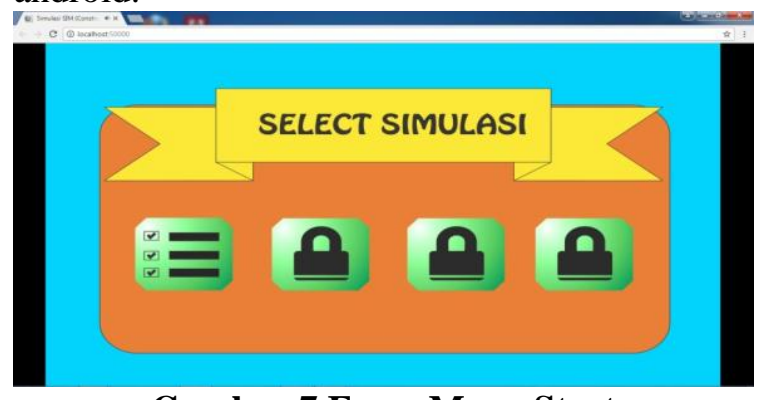

\section{Gambar 7 Form Menu Start}

\section{Form Menu Praktek}

Form menu tes praktek adalah form yang digunakan oleh pengguna untuk memulai tes praktek dengan menjalankan tes praktek ini dengan benar maka pengguna dapat lanjut ke tahap selanjutnya. Berikut gambar 8 dari form menu tes praktek pada aplikasi simulasi membuat SIM C berbasis android.

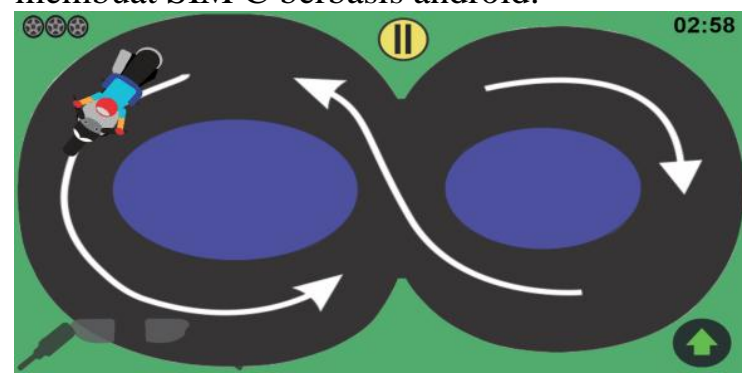

Gambar 8 Form Menu Tes Praktek

\section{Form Menu Option}


Form menu Option adalah form yang mana pengguna bias mengontrol suara audio. Berikut gambar 9 dari form option pada aplikasi simulasi membuat SIM C berbasis android.

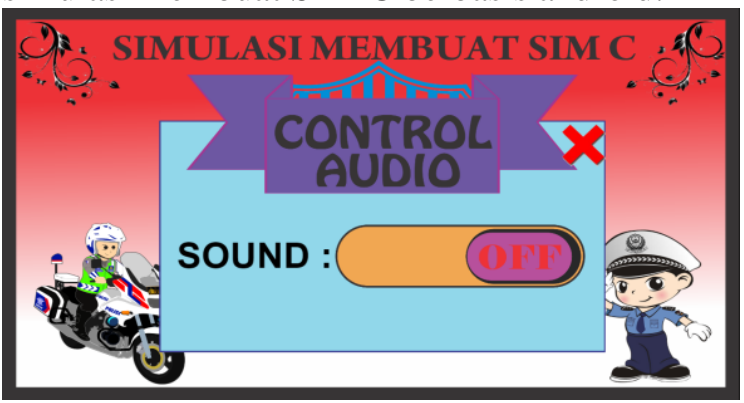

Gambar 9 Form Menu Option

\section{Form Menu About}

Form menu about adalah form yang mana pengguna bias melihat tentang isi profil pembuat aplikasi tersebut. Berikut gambar 10 dari form menu about pada aplikasi simulasi membuat SIM C berbasis android.

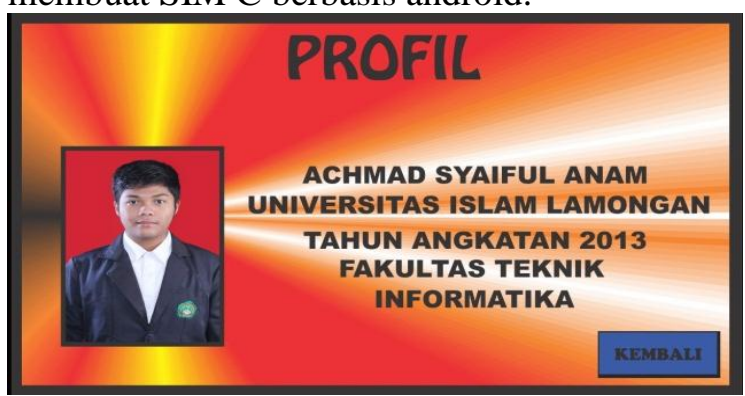

Gambar 10. Form Menu About

\section{Form Menu Video}

Form menu video adalah form yang mana pengguna dapat melihat video tutorial tentang tes praktek. Berikut gambar 11 dari form menu exit pada aplikasi simulasi membuat SIM C berbasis android.

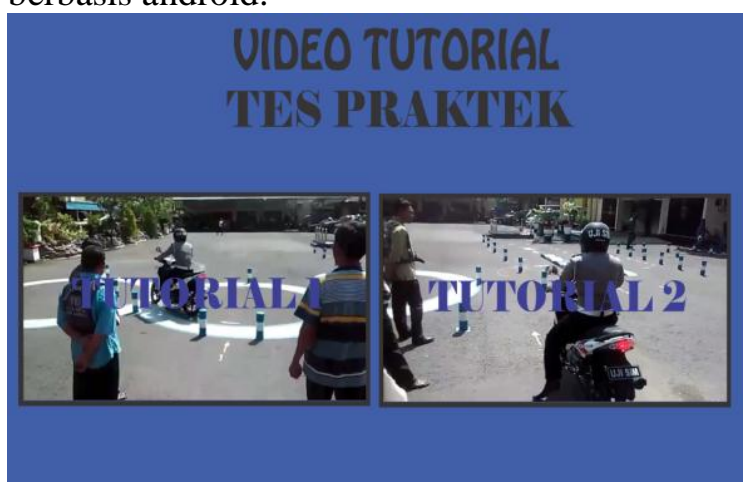

Gambar 11. Form Menu Video

\section{Form Menu Exit}

Form menu exit adalah form keluar yang nantinya pengguna akan memilih keluar atau tidak dari aplikasi tersebut. Berikut gambar 12 dari form menu exit pada aplikasi simulasi membuat SIM C berbasis android.

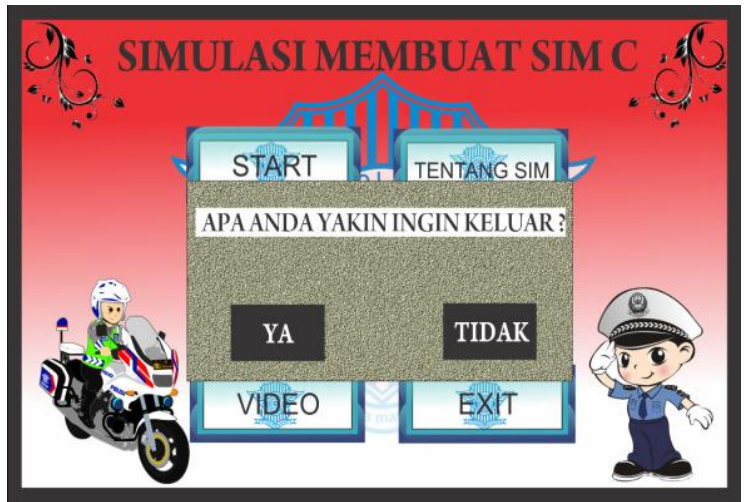

Gambar 12. Form Menu Exit

\section{HASIL DAN PEMBAHASAN \\ Uji Coba Sistem Dan Program}

Black box testing adalah metode pengujian perangkat lunak yang tes fungsionalitas dari aplikasi yang bertentangan dengan struktur internal atau kerja(lihat pengujian white box), pengetahuan khusus dari kode aplikasi/struktur internal dan pengetahuan pemrograman pada umumnya tidak diperlukan. Uji kasus dibangun di sekitar spesifikasi dan persyaratan yakni metode uj coba black box memfokuskan pada keperluan fungsional dari software. Kerena itu ujicoba black box memungkinkan pengembang software untuk membuat himpunan kondisi input yang akan melatih seluruh syarat-syarat fungsional suatu program ujicoba black box bukan merupakan alternatif dari ujicoba white box, tetapi merupakan pendekatan yang melengkapi untuk menemukan kesalahan lainnya.

\section{Hasil Kuisoner}

Hasil kuisoner dari 50 responden sebagai berikut :

1. Responden yang menjawab SS (Sangat Setuju) dengan skor 5 berjumlah 21 orang.

2. Responden yang menjawab S (Setuju) dengan skor 4 berjumlah 12 orang.

3. Responden yang menjawab N (Netral) dengan skor 3 berjumlah 10 orang.

4. Responden yang menjawab TS (Tidak Setuju) dengan skor 2 berjumlah 5 orang.

5. Responden yang menjawab STS (Sangat Tidak Setuju) dengan skor 1 berjumlah 2 orang.

Tabel 1. Bobot Nilai

\begin{tabular}{|l|l|}
\hline $\mathbf{A}$ & 5 \\
\hline $\mathbf{B}$ & 4 \\
\hline $\mathbf{C}$ & 3 \\
\hline $\mathbf{D}$ & 2 \\
\hline $\mathbf{E}$ & 1 \\
\hline
\end{tabular}


Tabel 2. Presentase Nilai

\begin{tabular}{|l|l|}
\hline Jawaban & \multicolumn{1}{|c|}{ Keterangan } \\
\hline $0 \%-19.99 \%$ & $\begin{array}{l}\text { Sangat (TidakSetuju, } \\
\text { Buruk atau Kurang } \\
\text { Sekali) }\end{array}$ \\
\hline $20 \%-39.99 \%$ & $\begin{array}{l}\text { Tidak Setuju atau } \\
\text { Kurang Baik }\end{array}$ \\
\hline $40 \%-59.99 \%$ & Cukup atau Netral \\
\hline $60 \%-79.99 \%$ & Setuju, Baik atau Suka \\
\hline $80 \%-100 \%$ & $\begin{array}{l}\text { Sangat (Setuju, Baik, } \\
\text { Suka) }\end{array}$ \\
\hline
\end{tabular}

Dari data yang didapat diatas kemudian diolah dengan cara mengkalikan setiap point jawaban dengan bobot yang sudah ditentukan dengan tabel bobot nilai.

Maka berdasarkan teori skala likert diperoleh rumus pernyataan kuisoner sebagai berikut :

Rumus : T x Pn

$\mathbf{T}=$ Total jumlah responden yang memilih

Pn = Pilihan angka skor Likert

1. Responden yang menjawab sangat setuju (5) $=30 \times 5=150$

2. Responden yang menjawab setuju $(4)=12$ $\mathrm{x} 4=48$

3. Responden yang menjawab netral $(3)=6 \times 3$ $=18$

4. Responden yang menjawab tidak setuju (2) $=3 \times 2=6$

5. Responden yang menjawab sangat tidak setuju $(1)=1$ x $1=1$

Total Skor $=150+48+18+6+1=223$

\section{Interpretasi Skor Perhitungan}

Untuk mendapatkan hasil interpretasi, harus diketahui dulu skor tertinggi (X) dan angka terendah (Y) untuk item penilaian dengan rumus sebagai berikut :

$\mathrm{Y}=$ Skor tertinggi likert $\mathrm{x}$ jumlah responden (Angka Tertinggi 5) "Perhatikan Bobot Nilai" $\mathrm{X}=$ Skor terendah likert $\mathrm{x}$ jumlah responden (Angka Terendah 1) "Perhatikan Bobot Nilai"

Jumlah skor tertinggi untuk item SANGAT SETUJU ialah $5 \times 50=250$, sedangkan item SANGAT TIDAK SETUJU ialah 1 x 50 $=50$. Jadi, jika total skor responden di peroleh angka 223, maka penilaian interpretasi responden terhadap media pembelajaran tersebut adalah hasil nilai yang dihasilkan dengan menggunakan rumus Index $\%$.

Rumus Index \% = Total Skor $/ Y$ x 100

]Maka penyelesaian akhir dari contoh kasus :

= Total Skor / Y x 100
$=223 / 250 \times 100$

$=89,2 \%=89 \%$ Kategori SANGAT SETUJU

Dari hasil di atas maka dapat disimpulkan bahwa responden SANGAT SETUJU aplikasi simulasi membuat SIM C ini dapat membantu responden dalam memberikan pengetahuan sebelum melakukan tes SIM C.

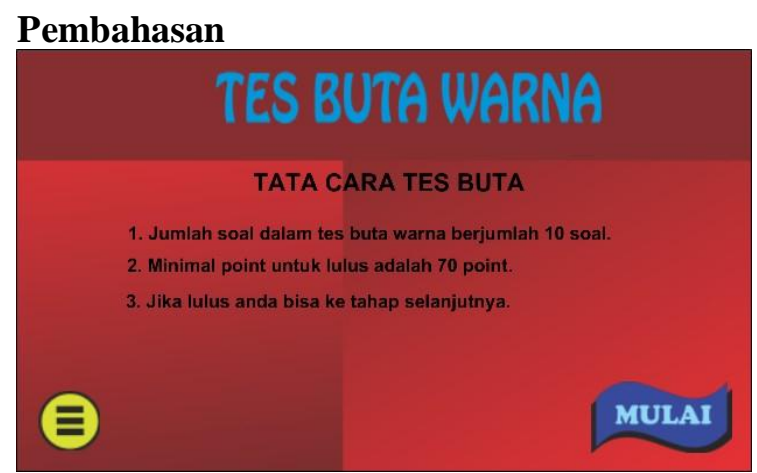

Gambar 13. Tampilan Tes Buta Warna

Pada tampilan tes buta warna tersebut terdapat dua tombol yaitu tombol mulai yang berfungsi untuk memulai tes buta warna, tombol berbentuk lingkaran yang berfungsi untuk kembali ke menu utama dan terdapat informasi tata cara tes buta warna. Gambar 14 adalah tampilan hasil tes buta warna :

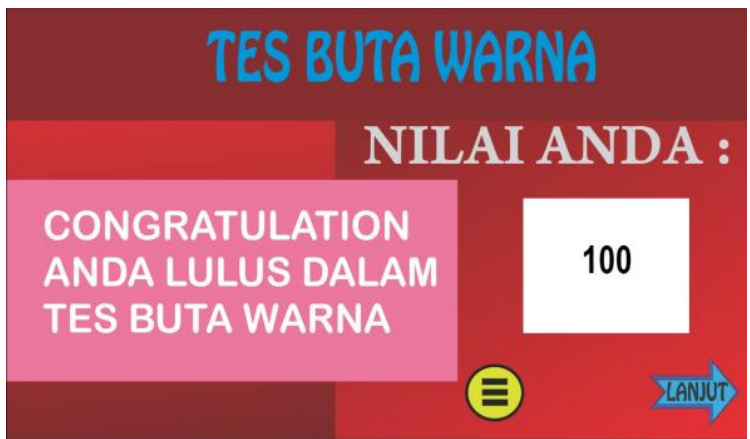

Gambar 14 Tampilan Hasil Tes Buta Warna

Jika tes buta warna selesai maka pengguna dapat lanjut pada tes berikutnya yaitu tes teori. Gambar 15 adalah tampilan tes teori :

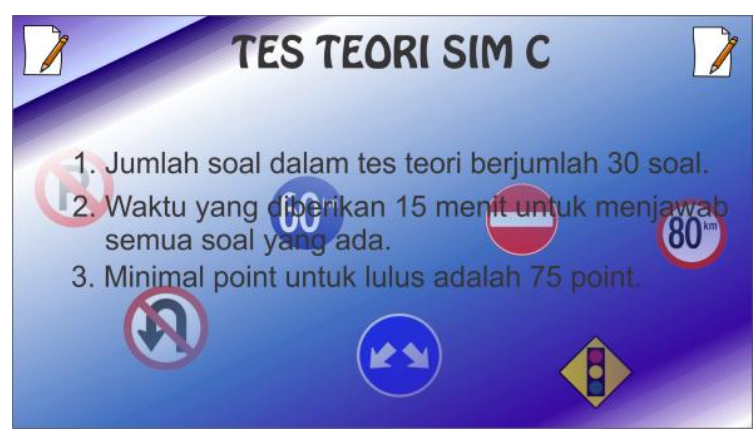

Gambar 15 Tampilan Tes Teori 
Pada tampilan tes teori ini terdapat tombol mulai untuk memulai tes teori simulasi SIM C dan juga terdapat informasi tentang tata cara tes teori. Gambar 16 adalah tampilan hasil tes teori:

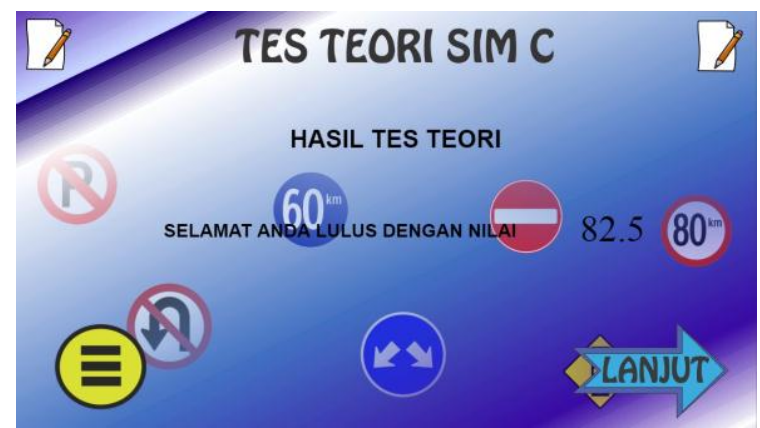

Gambar 16 Tampilan Hasil Tes Teori

\section{KESIMPULAN DAN SARAN}

\section{Kesimpulan}

Dari uraian dan pembahasan yang telah dilakukan, maka dapat diambil beberapa kesimpulan sebagai berikut :

Aplikasi ini dirancang menggunakan Construct 2, tahapan merancang aplikasi simulasi membuat SIM $\mathrm{C}$ ini dimulai dengan pengumpulan data (soal buta warna, tes teori, informasi tes praktek, dan informasi tentang SIM), selanjutnya mendesain interface pada program dan kemudian merancang alur sistem program, terakhir melakukan uji coba Black Box dan uji coba user.

Hasil implementasi uji coba internal (pembuatan) aplikasi simulasi membuat SIM C ini berhasil berdasarkan uji coba menggunakan metode Black Box.

Hasil implementasi uji coba user berdasarkan perhitungan kuisoner responden sebanyak 50 orang menggunakan metode skala likert diperoleh hasil $89 \%$. Maka dapat diambil kesimpulan bahwa aplikasi simulasi membuat SIM C ini dikategorikan sangat baik.

\section{Saran}

Untuk lebih memahami tentang sebuah aplikasi simulasi membuat SIM C diperlukan pemahaman program aplikasi tes simulasi yang baik. Untuk itu saran yang diberikan yaitu :

1. Aplikasi simulasi membuat SIM C ini hanya dapat dimainkan secara single player. Untuk kedepan, aplikasi ini dapat dikembangkan dengan lebih menarik lagi dan tes yang lebih lengkap.

2. Pengembangan aplikasi simulasi membuat SIM C pada platform lain dengan sistem operasi yang berbeda seperti iOS, Windows Phone, dan lain-lain.

\section{DAFTAR PUSTAKA}

[1] Basuki. 2015. rancangan aplikasi berbasis android untuk pengenalan rambu lalu lintas serta latihan ujian teori sim. (online), diakses 20 maret 2017.

[2] Santiae. 2015. Aplikasi Realisasi Penerimaan RTW (Rail Tank Wagon) pada PT Pertamina (Persero) Terminal Bahan Bakar Minyak (TBBM) Lahat. (Online), Diakses 20 Maret 2017.

[3] Gusriani, Uci. 2015. Pelayanan Pengurusan Surat Izin Mengemudi (Sim) Di Kantor Kepolisian Resort Kota (Polresta) Samarinda. (Online), Diakses 20 Maret 2017.

[4] Purwanto, Nugraha Heru. 2014. Pengertian Simulasi Digital. (Online), Diakses 20 Maret 2017.

[5] Setiawan, Dannise, Victor, Sucipto, Saka Parwa. 2016. Analisis Dan Perancangan Sistem Kontrol Kamar Hotel Berbasis Wifi Dan Android. (Online), Diakses 20 Maret 2017.

[6] Meidianto, Dhian. 2015. Aplikasi Informasi Nilai Berbasis Sms Gateway Pada Stmik Raharja. (Online), Diakses 20 Maret 2017. 
Halaman ini sengaja dikosongkan 